\title{
Combining three in vitro assays for detecting early signs of UVB cytotoxicity in cultured human skin fibroblasts
}

\author{
C. Khalil \\ School of Safety Science, \\ Chemical Safety and Applied Toxicology Laboratories, \\ University of New South Wales, Sydney, Australia
}

\begin{abstract}
The aim of this study was to determine the most sensitive approach for detecting the early signs of UVB-induced cellular damage using human skin fibroblasts. UVB-induced cell damage was assessed immediately and $24 \mathrm{~h}$ post irradiation using 3 in vitro colorimetric assays: neutral red (NR); 5-(3-carboxymethoxyphenyl)-2-(4.5-dimethylthiazolyl)-3-(4-sulphonyl) MTS; and (iii) LDH enzyme release. A good correlation was observed immediately post exposure between the MTS and NR in measuring damage levels, but was lost $24 \mathrm{~h}$ post exposure. This loss of correlation was the result of delayed expression of lysosomal damage and led to investigating cell membrane damage using LDH cell leakage assay. LDH levels observed immediately post UVB irradiation indicated significant LDH release at exposure doses of 2.2 and $2.8 \mathrm{~J} / \mathrm{cm}^{2}$, while $\mathrm{LDH}$ release reported $24 \mathrm{~h}$ post exposure was recorded for doses as low as 0.70 $\mathrm{J} / \mathrm{cm}^{2}$. The data reported in this paper indicated that cell viability and damage were significantly affected in a dose dependent manner as a result of exposure doses. The assays used displayed different sensitivities in detecting damage with the earliest signs of cellular UVB damage best-measured $24 \mathrm{~h}$ following exposure using the LDH assay. Furthermore UVB contributed to denaturing the cellular LDH released during irradiation. Therefore the use of LDH cytotoxicity based assays with UVB exposure must be considered with extreme care. Keywords: cells, viability, MTS, neutral red, UVB, LDH, cytotoxicity.
\end{abstract}




\section{Introduction}

The current degradation of the ozone layer by CFC's and other man made chemicals triggered major concerns about the harmful effects of environmental exposure to solar radiation and their impacts on climate, environmental processes and life on earth (Kledsen and Scheutz [1]). Among the spectrum of UV radiation emitted by the sun UVB is thought to be the major cause of skin damage and long-term health risks. The effects of UVB (290-320 nm) radiation on human skin can be seen as acute (sunburn and inflammation) (Grassen and van Loveren [2]) or chronic (photoaging and skin cancer) ([2]; Tebbe et al. [3]; Deliconstantinos et al. [4]). The acute effects of UVB are thought to be mediated by cytokine production leading to cell death (early apoptosis) (Petit-Frere et al. [5]; Norris et al. [6]; Gniadecki et al. [7]; Corsini et al. [8]).

The human skin is composed of a variety of cells including skin fibroblasts. These cells by virtue of their location, numbers in the dermis, and ease of growth in culture could be used as possible indicators of cellular damage caused by UVB irradiation.

This study explored a number of approaches for detecting the early signs of UVB damage through the use of an artificial UVB source coupled with primary cell cultures of human skin fibroblast to mimic exposure pattern observed in vivo. This approach was adopted to investigate UVB exposure induced damage (mitochondrial, lysosomal and membrane damage) and to understand the different level of damage expression within cell organelles.

This non-invasive in vitro study and the data generated represented a suitable alternative for using whole animal models for assessment of toxicity of UVB exposure and assisted in reducing uncertainties in data extrapolation from animals to humans due to the use of human skin fibroblasts cells. Furthermore, the techniques used are rapid and reproducible as they generated toxicity profiles within hours of running the assays (Bakand et al. [9]).

The in vitro assays selected are modified cytotoxicity tests (MTS, NR and $\mathrm{LDH}$ ) developed by our lab and used extensively in measuring different biological end points ([9]; Lestari et al. [10]).

The main purpose of this study was to identify the most sensitive assay for measuring early signs of UVB exposure cytotoxicity immediately and $24 \mathrm{~h}$ post UVB exposure in addition to understanding the limitations of the in vitro assays used.

\section{Materials and methods}

\subsection{Cell cultures}

Primary fibroblast cell cultures were derived from human skin biopsies [Children's Hospital Westmead (Australia)] and maintained in short term cell culture. Cells were subcultured as adherent cells in $75 \mathrm{~cm}^{2}$ tissue culture flasks with $0.2 \mu \mathrm{m}$ vented seals (Falcon). The culture media consisted of colour free 
Dulbeco's modified eagle medium (DMEM): RPMI 1640 (1:1) purchased from Sigma Chemicals, supplemented with $5 \%$ foetal calf serum (Trace Bioscience), $3 \%$ Sigma antibiotics [penicillin $(100 \mathrm{U} / \mathrm{ml})$, streptomycin $(0.1 \mathrm{mg} / \mathrm{ml})$ and $\mathrm{L}-$ glutamine $(2 \mathrm{mM})]$. The cell lines were cultured at $37^{\circ} \mathrm{C}$ at sub-confluence in a humidified incubator set to a mixture of $5 \% \mathrm{CO}_{2} / 95 \%$ air. Cell viability was over $95 \%$ as measured by tryptan blue dye exclusion.

Confluent cells in $\log$ phase of growth were released from the bottom of the culture flask using Trypsin EDTA (Gibco, USA), and then washed three times with cell culture medium. This was followed by a cell count/cell viability assessment before the cells were seeded on 24 well plates and incubated overnight to allow cells to reattach to the bottom of plates before UVB irradiation.

The seeding density of cells to the 24 well plates was previously determined and cells were seeded at a density of $500,000 \mathrm{cells} / \mathrm{ml}$ based on the linearity range studies (cell concentration versus absorbance) previously conducted [9].

\subsection{UVB irradiation}

For UVB irradiation medium was replaced with Hank's Balanced Salt solution (HBBS Gibco, USA), the coverlids of the 24 well microtiter plate removed and cells exposed to UVB irradiation $\left(3.92 \times 10^{-4} \mathrm{~W} / \mathrm{cm}^{2}\right)$ from a 6 lamps (FS40212) supplied by Wayne Electronics (Somersby, Australia). The output of the lamps was measured by an IL-1700 research radiometer (International Light, Newbury Port, MA).

Cells were irradiated with UVB doses ranging from 0.0078 to $5.6 \mathrm{~J} / \mathrm{cm}^{2}$. The procedure followed in the assay immediately post exposure consisted of removal of exposure medium (HBSS) following UV exposure and subjecting the cells to the cytotoxicity assays. The 24 hour exposure protocol consisted of replacing the UVB exposure medium (HBSS) post exposure with culture medium, incubating the cells for $24 \mathrm{~h}$ in a $\mathrm{CO}_{2}$ incubator then subjecting the cells to the cytotoxicity assays.

\subsection{Cytotoxicity assays}

The MTS assay (Promega, USA) was selected for measuring the number of active cells in the culture (based on the lactated dehydrogenase activity in the mitochondria). The MTS assay measuring the conversion of a soluble tetrazolium salt to a formazan product by viable cells. The assay consisted of an MTS solution prepared by mixing a solution of MTS ( $42 \mathrm{mg}$ MTS powder in 21 $\mathrm{ml}$ of DPBS $\mathrm{pH}$ 6.0-6.5) with a PMS solution $(0.92 \mathrm{mg} / \mathrm{ml}$ PMS in DPBS) to the cells to be tested in a ratio of 1:5. The MTS was then incubated with the cells for a period of $2 \mathrm{~h}$ at $37^{\circ} \mathrm{C}$ in the dark. After $2 \mathrm{~h}$, the cellular supernatant was removed for measurement. The amount of reduced Formazan was assessed by measuring the optical density at $492 \mathrm{~nm}$ using a Labsystem Multiskan MS plate reader. Data was plotted as a dose response curve exposure versus absorbance reading. 
The NR assay (Sigma, USA) is a cell survival assessment technique that measures the uptake of the neutral red dye by viable cells. The procedure consisted in removal of exposure medium following UV exposure (under sterile conditions), this was followed by the addition of $0.33 \%$ neutral red solution (Sigma Chemicals, USA) in an amount equal to $10 \%$ of the initial culture media volume, followed by an incubation period of $2 \mathrm{~h}$, then cells are fixed (NR Assay Fixative $\left(1 \%(\mathrm{wt} / \mathrm{v}) \mathrm{CaCl}_{2}: 0.5 \%(\mathrm{v} / \mathrm{v})\right.$ Formalin)) before addition of an assay solubilization solution (1\% (v/v) Acetic acid: $50 \%$ (v/v) Ethanol). The amount of dye incorporated in the cells measured using the Multiskan plate reader using a $540 \mathrm{~nm}$ reading wavelength with background absorbance reading measured at $690 \mathrm{~nm}$ and subtracted from the $540 \mathrm{~nm}$ measurement.

The LDH assay (Promega Corporation) measured the amount of lactate dehydrogenase released by the cells upon UV insult. Released LDH in cultures was measured with a 30 minutes coupled enzymatic assay which resulted in the conversion of the tetrazolium salt into a red colored formazan product. The protocol supplied by Promega (Technical Bulletin 163) was followed without any alterations. $50 \mu \mathrm{l}$ of exposure media was transferred to a mutliwell plate. 12 $\mathrm{ml}$ of the assay buffer was mixed with the substrate mix and $50 \mu \mathrm{l}$ of this solution added to each well of the plate. Cells were incubated for 30 minutes in the dark. This incubation period was followed by the addition of $50 \mu \mathrm{l}$ of the stop solution $(0.1 \mathrm{M} \mathrm{HCL})$ to each well. The plates were spectrophotometrically processed within $1 \mathrm{~h}$ at $492 \mathrm{~nm}$.

\subsection{Statistical analysis}

The dose response curves reported were plotted from the experimental data and the background absorbance subtracted from the presented graphical pots. All the data reported was expressed as the mean \pm SD of 4 replicated wells. Statistical procedures and graphical analysis were performed using Microsoft Excel software.

\section{Results}

\subsection{Cytotoxicity assessment of UVB-exposed on human skin fibroblasts with the MTS and NR assays immediately post exposure}

The experimental investigations used skin fibroblasts cultures at a density of 50,000 cells $/ 100 \mu$ l exposed to UVB doses $\left(0-5.6 \mathrm{~J} / \mathrm{cm}^{2}\right)$ with damage levels assessed by two cytotoxicity assays MTS and NR are summarized in Figure 1.

Correlation analysis between the two cytotoxicity assays (Figure 2) showed that there was a direct agreement between the MTS and NR assays in measuring damage extent $\left(\mathrm{R}^{2}=0.70\right)$ immediately post exposure although they were measuring damage levels at different cellular compartments. 


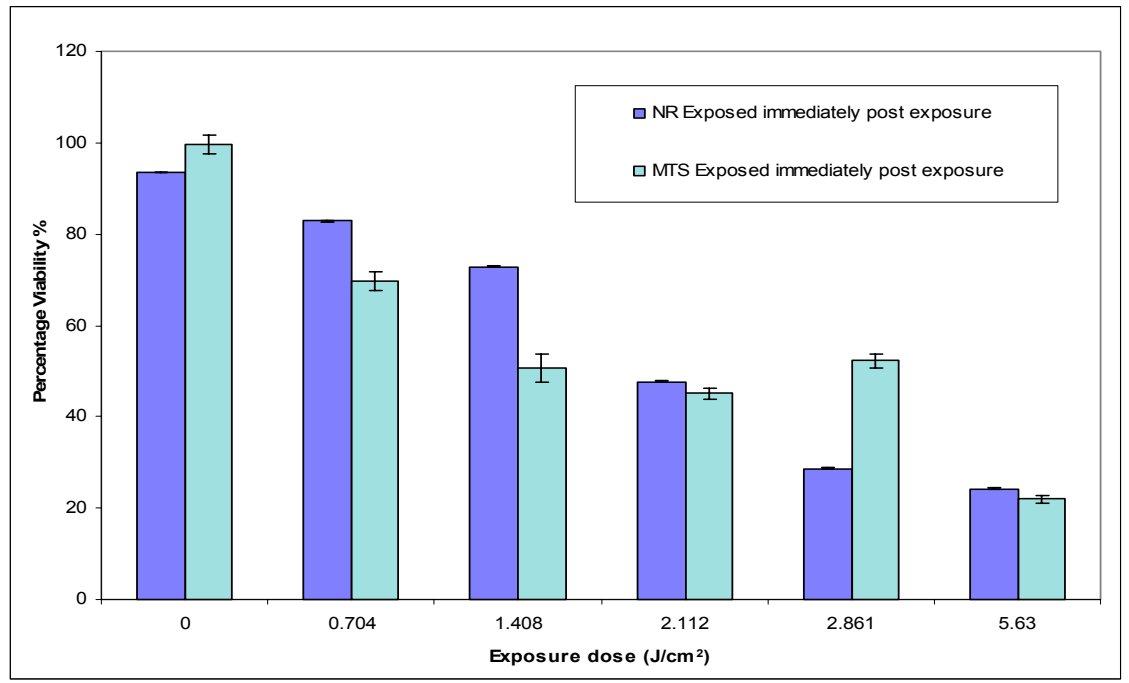

Figure 1: $\quad$ Relationship between UVB dose and cell viability as measured by the MTS and NR assays immediately post exposure. Values are mean \pm SD of at least 4 experimental replicates.

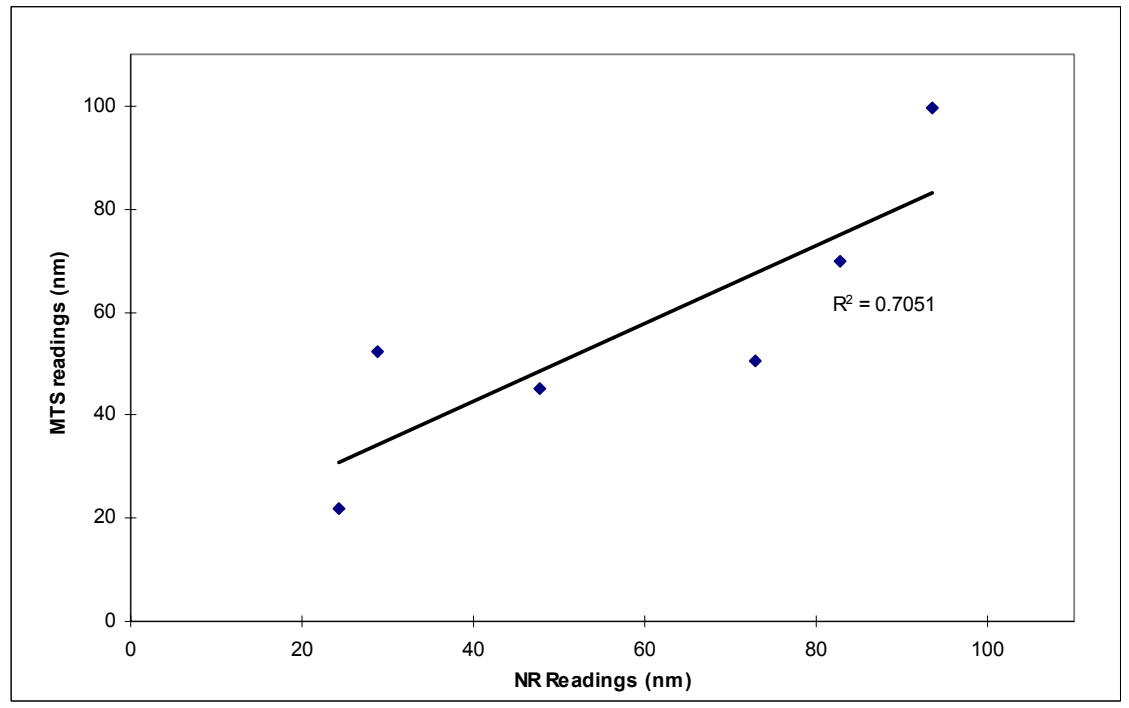

Figure 2: Correlation between MTS and neutral red assay in evaluation of UVB-induced toxicity following skin fibroblasts exposure. 


\subsection{Cytotoxicity assessment of UVB-exposed on human skin fibroblasts with the MTS and NR assays $24 \mathrm{~h}$ post exposure}

Primary skin fibroblasts $\left(46 \times 10^{3}\right.$ cells/100 $\left.\mu \mathrm{l}\right)$ were exposed to UVB and cultured for $24 \mathrm{~h}$ post exposure before cytotoxicity assays. The exposure of skin fibroblasts cells to UVB doses and their impacts on cellular viability $24 \mathrm{~h}$ postexposure are outlined in Figure 3.

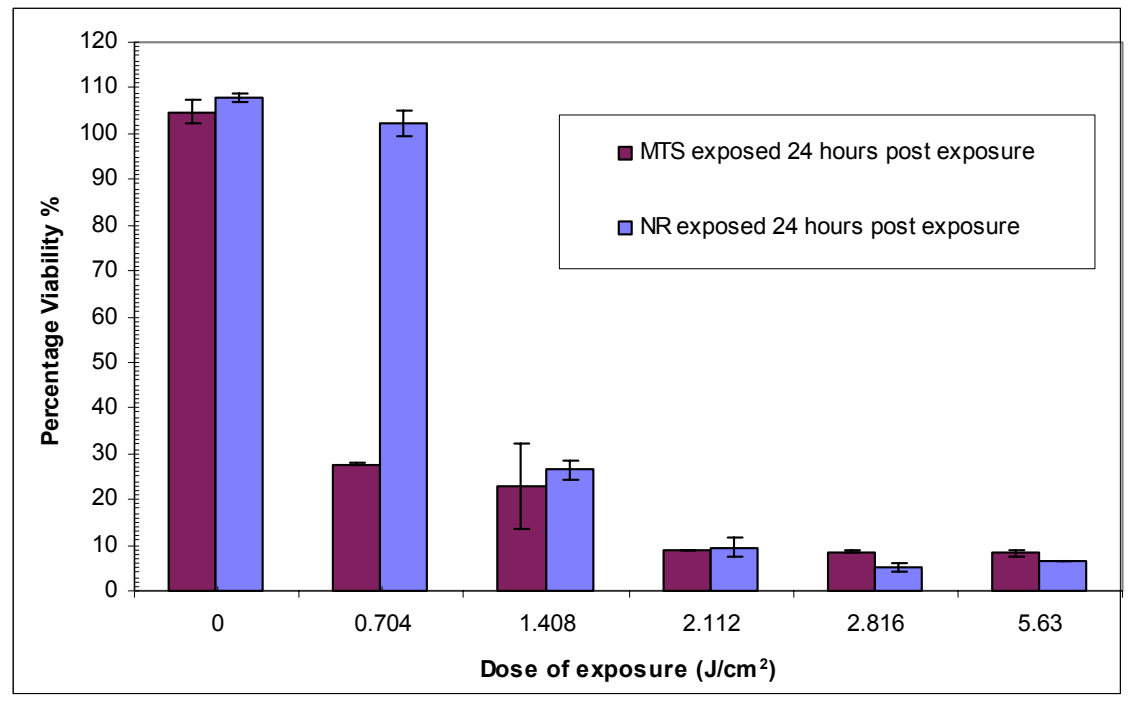

Figure 3: Relationship between UVB dose and cell viability as measured by the MTS and NR assays $24 \mathrm{~h}$ post exposure. Cell media was removed and replaced with $400 \mu \mathrm{L}$ HBSS for UVB exposure.

Cytotoxicity results using the MTS assay illustrated in Figure 3 showed the sensitivity of the MTS test in detecting the effects of UVB radiation on cellular processes. By contrast to the MTS assay, the NR assay did not exhibit the same level of sensitivity in detecting early cell membrane damage under the same exposure conditions especially at low exposure doses. This discrepancy at exposure dose of $0.704 \mathrm{~J} / \mathrm{cm}^{2}$ between the 2 assays contributed to the loss of correlation $24 \mathrm{~h}$ post exposure. Therefore, no correlation could be established between the MTS and neutral red cytotoxicity test for UVB exposure of skin fibroblasts $24 \mathrm{~h}$ post exposure.

\subsection{Measurement of LDH activity in UVB exposed skin fibroblasts}

The discrepancy in measuring damage levels observed in Figure 3 lead to further experimentation to investigate the extent of cell membrane damage upon UVB exposure. These experiments consisted of exposing skin fibroblasts cells to variable UVB doses and determining cell membrane integrity immediately and 
$24 \mathrm{~h}$ post-exposure by assessing LDH leakage from damaged cells. In the experiments LDH release assay was performed on both the HBSS from exposed cells and the media of incubation (the background readings were considered and subtracted from all values). The data was reported in Figure 4.

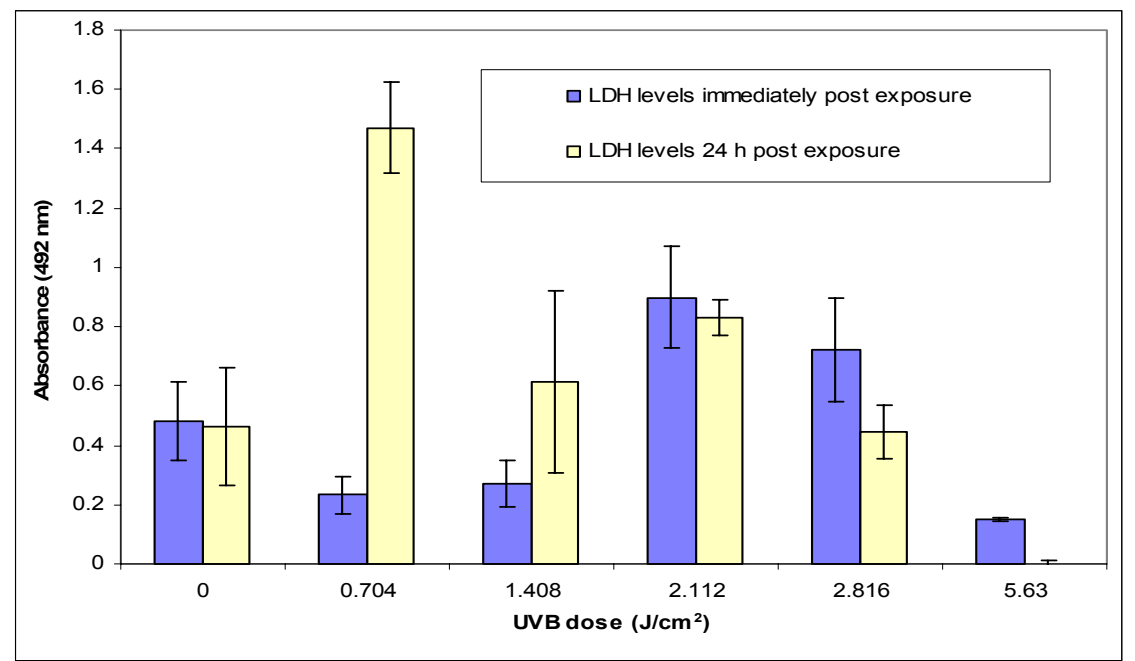

Figure 4: $\quad$ Skin fibroblasts LDH release immediately and 24h post UVB dose exposure. LDH levels in HBSS (exposure media) following UVB irradiation of skin fibroblasts.

The readings reported at $0.704 \mathrm{~J} / \mathrm{cm}^{2} \mathrm{UVB}$ dose, especially the lower than expected result for the immediate measurement of LDH release led to exposing cell fibroblasts cultures to low doses and trying to further clarify this result discrepancy. Cells were exposed UVB doses ranging from 7.8 to $250 \mathrm{~mJ} / \mathrm{cm}^{2}$ and release of LDH immediately and $24 \mathrm{~h}$ post exposure compared in Figure 5.

\section{Discussion}

Ozone depletion is of major concern to the future of life on the planet due to its important role in filtering ultraviolet radiation (Kalbin et al. [11]). This paper attempts to investigate cellular damage triggered by a range of UVB radiation in vitro using human skin fibroblasts as the target cells. The assessment of cellular damage was achieved by 3 colorimetric assays selected for their reliability and reproducibility $[9,10]$.

The cytotoxicity of UVB exposure on human skin fibroblast was studied using the MTS, NT and LDH assays. This study compared and correlated the results of those assays immediately and $24 \mathrm{~h}$ post exposure.

The results in Figure 1 showed a dose response relationship between exposure and cellular mitochondrial dehydrogenase activity immediately post UVB 
exposure as measured by the MTS assay. The decrease in the mitochondrial activity was dose dependent and directly associated with increased UVB dose. The exposure of human skin fibroblast to a dose of $2.11 \mathrm{~J} / \mathrm{cm}^{2}$ of UVB reduced the mitochondrial activity to $50 \%$, while at $5.6 \mathrm{~J} / \mathrm{cm}^{2}$ of UVB radiation activity was reduced to $20 \%$. The relationship between UVB exposure and cellular viability immediately post exposure was further investigated using the NR assay. The damage caused by UVB was assessed by determining the reduction in NR dye uptake by the lysosomes as cells with damaged cellular membranes cannot retain the dye. NR decreased uptake by exposed cells could be directly related to UVB exposure (Figure 1). The data in Figure 1 showed a decrease in the uptake of NR dye with increased UVB dose. The exposure of the cellular cultures to UVB dose of $2.1 \mathrm{~J} / \mathrm{cm}^{2}$ decreased the viability to less than $50 \%$. The existence of a potential correlation between membrane damage and reduced mitochondrial activity was investigated in Figure 2 . The $\mathrm{R}^{2}$ value $(0.70)$ for this correlation showed a good agreement between the two assays in measuring damage at different levels (mitochondrial and lysosomal damage) immediately post exposure within the exposed cells.

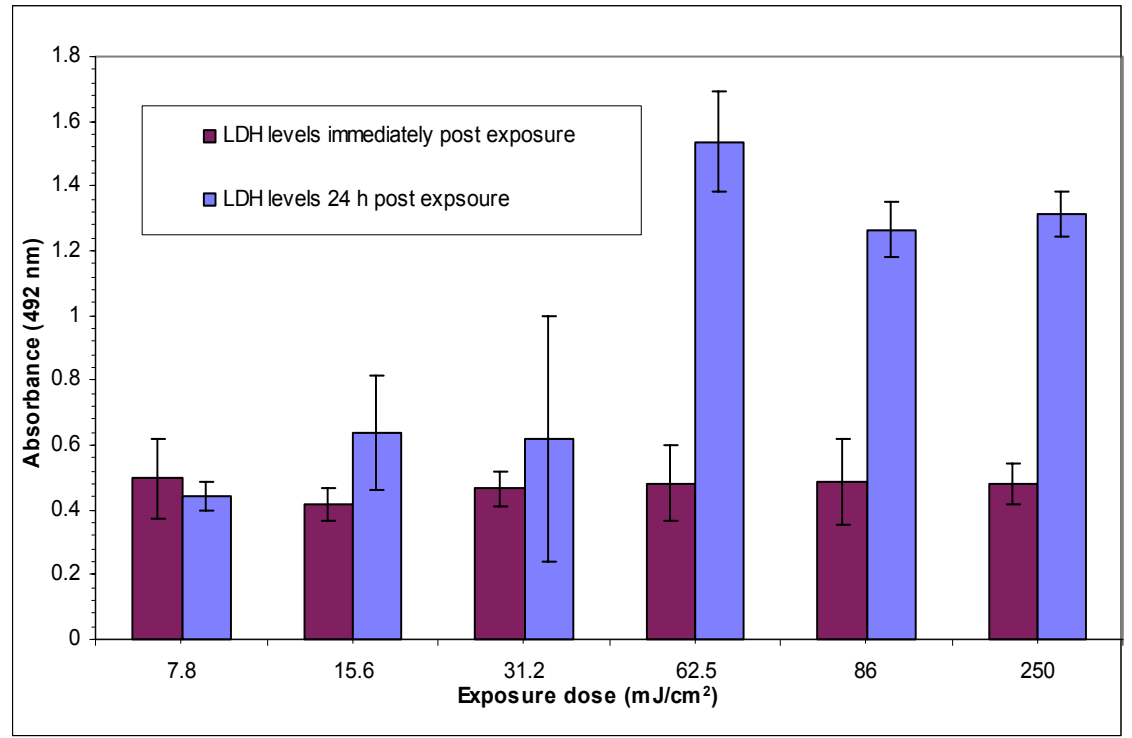

Figure 5: Upregulation of LDH extracellular release upon low dose exposures immediately and $24 \mathrm{~h}$ post exposure.

The cytotoxicity of skin fibroblast UVB exposure was also investigated $24 \mathrm{~h}$ post exposure and reported in Figure 3. Comparison of the observed damage 24 $\mathrm{h}$ post exposure to a UVB dose of $0.70 \mathrm{~J} / \mathrm{cm}^{2}$ clearly indicated the higher sensitivity of the MTS assay (compared to NR assay) in measuring early damage. The NR data showed no significant difference between the viability of controls and exposed cells $\left(0.7 \mathrm{~J} / \mathrm{cm}^{2}\right)$. 
The correlation between the MTS and NR assays absorbance readings reported immediately post exposure was absent $24 \mathrm{~h}$ post exposure. This loss of correlation could be mainly attributed to the greater sensitivity of the MTS assay (by comparison to NR) at a dose of $0.70 \mathrm{~J} / \mathrm{cm}^{2}$. No significant difference ( $>0.01$ ) could be reported at a dose of $0.70 \mathrm{~J} / \mathrm{cm}^{2}$ between exposed and control cells as measured by NR assay. This indicated a delayed expression of lysosomal damage upon UVB exposure by skin fibroblasts $24 \mathrm{~h}$ post exposure, although published research in this regard (Debacq-Chainiaux et al. [12]) established that doses higher than $0.5 \mathrm{~J} / \mathrm{cm}^{2}$ were needed to trigger a significant reduction in fibroblast cell viability.

The delayed expression of lysosomal damage reported $24 \mathrm{~h}$ post UVB exposure $\left(0.7 \mathrm{~J} / \mathrm{cm}^{2}\right)$ led to further examination of lysosomal toxicity by determining whether the low lysosomal damage observed in the NR data could be compared to overall cell membrane UVB exposure damage as measured by the LDH leakage assay (Figure 4).

UVB exposure $\left(0.7\right.$ to $\left.5.6 \mathrm{~J} / \mathrm{cm}^{2}\right)$ of skin fibroblasts triggered significant $\mathrm{LDH}$ release immediately and $24 \mathrm{~h}$ post exposures. UVB exposure triggered an LDH peak observed at $2.1 \mathrm{~J} / \mathrm{cm}^{2}$ immediately post exposure. This was followed by a decrease in the LDH levels to below control cell levels for a dose of $5.6 \mathrm{~J} / \mathrm{cm}^{2}$ (Figure 4). The examination of LDH release for doses lower than $2.11 \mathrm{~J} / \mathrm{cm}^{2}$ indicated a significant reduction in the amount of LDH detected by comparison to the control levels. The extracellular LDH release ( $24 \mathrm{~h}$ post exposure) was also reported in Figure 4. UVB was found to cause a peak in LDH activity at a UVB dose of $0.7 \mathrm{~J} / \mathrm{cm}^{2} 24 \mathrm{~h}$ post exposure. This peak was followed by a decrease in the extracellular LDH detected.

These deviations in LDH levels from the expected results (significant upregulation of LDH leakage for doses of 0.70 and $1.4 \mathrm{~J} / \mathrm{cm}^{2}$ immediately post UVB exposure) led to studying lower UVB doses $\left(7.8-250 \mathrm{~mJ} / \mathrm{cm}^{2}\right)$ to establish whether LDH release was affected. It was observed that there was no releases of LDH immediately post exposure while a significant dose dependent LDH release was observed $24 \mathrm{~h}$ post exposure. The LDH extracellular release $24 \mathrm{~h}$ post exposure peaked at UVB dose of $62.5 \mathrm{~mJ} / \mathrm{cm}^{2}$ before reaching a plateau due to reaching the upper detection limit of the Multiskan reader used. Furthermore, no decrease in LDH release to levels below control levels was recorded. This increase in LDH release upon UVB exposure agrees with published literature on UVB exposed murine fibroblast (Kimura et al. [14]) where it was reported that LDH activity increased in cells treated with UVB up to $72 \mathrm{~h}$ post exposure.

This increase in LDH release was followed by a decrease for doses higher than $2.5 \mathrm{~J} / \mathrm{cm}^{2}$ (Figure 4). The observed decrease in LDH release was possibly the result of LDH deactivation by UVB rays. The LDH levels detected $24 \mathrm{~h}$ post UVB exposure to doses ranging from 0.7 to $5.6 \mathrm{~J} / \mathrm{cm}^{2}$ appeared to peak at a dose of $0.7 \mathrm{~J} / \mathrm{cm}^{2}$ with a gradual decrease. This was predictable since the cellular viability was significantly reduced $24 \mathrm{~h}$ post UVB exposure as reported by the MTS and NR data (Figure 3).

Based on these results it was hypothesized that the observed reduction of LDH levels observed for doses ranging from 1.7-0.4 J/ $\mathrm{cm}^{2}$ could be the result of 
LDH de-activation by UVB rays. This hypothesis was validated by subjecting a serial LDH dilutions $(0.066 \mathrm{u} / \mathrm{ml}, 0.033 \mathrm{u} / \mathrm{ml}, 0.0165 \ldots)$ to variable UVB doses $\left(0-5.6 \mathrm{~J} / \mathrm{cm}^{2}\right)$. It was observed that high UVB doses combined with low LDH concentration significantly reduced LDH activity as shown in Figure 6. The data reported in Figure 6 agreed with other research (Artiukhova et al. [13]) that reported similar decrease in LDH activity in UV exposed LDH.

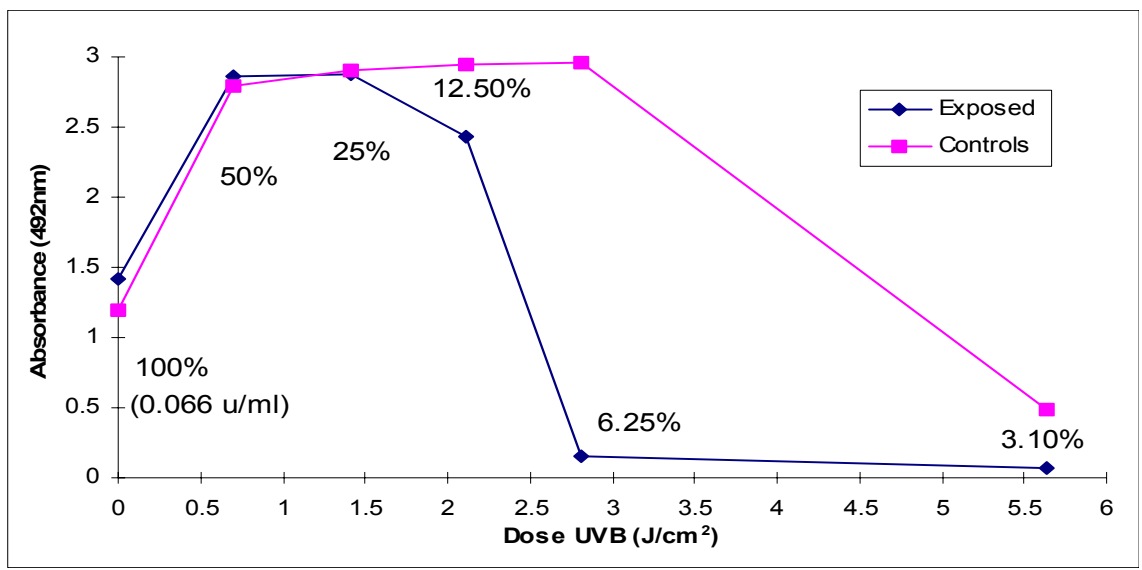

Figure 6: Effect of UVB doses on the enzymatic activity of serial dilutions of an LDH stock solution $(0.066 \mathrm{u} / \mathrm{ml})$ subjected to UVB to determine its effects on LDH activity. Low levels of LDH (12.5 and 6.25\%) were affected by UVB irradiation higher than $2.5 \mathrm{~J} / \mathrm{cm}^{2}$ with lower enzymatic activity recorded.

It is concluded from the data presented in this paper that the three in vitro methods used were suitable for testing the impact of UVB on cellular functions. We found that the three assays complement each other as they were measuring different end-points. The detection of the early damage levels triggered by UV exposure was best achieved $24 \mathrm{~h}$ post exposure using the LDH assay. The MTS and NR were also valuable tools for damage assessment immediately and $24 \mathrm{~h}$ post although they displayed lower sensitivity than the LDH assay.

\section{References}

[1] Kledsen, P. \& Scheutz, C., Short and long term release of Fluorocarbons from disposal of polyurethane foam waste. Environmental Science Technology. 37, pp 5071-5079, 2003.

[2] Garssen, J., van Loveren, H., Effects of ultraviolet exposure on the immune system (review), Critical Reviews in Immunology 21 (4), pp 359$397,2001$.

[3] Tebbe, B., Wu, S., Geilen, C.C., Eberle, J., Kodelja, V., Orfanos, C.E., Lascorbic acid inhibits UVA-induced lipid peroxidation and secretion of 
IL-1 $\alpha$ and IL-6 in cultured human keratinocytes in vitro, Journal of Investigative Dermatology 108, pp 302-306, 1997.

[4] Deliconstantinos, G., Villiotu, V., Stavrides, J.C. Nitric oxide and peroxynitrite released by ultraviolet B-irradiated human endothelial cells are possibly involved in skin erythema and inflammation. Experimental Physiology 81, pp 1021-1033, 1996.

[5] Petit-Frere, C., Capulas, E., Lyon D.S., Norbury, C.J., Lowe, J.E., Clingen, P.H., Riballo, E., Green, M.H., Arlett, C.F., Apoptosis and cytokine release induced by ionizing or ultraviolet $\mathrm{B}$ radiation in primary and immortalized human keratinocytes. Carcinogenesis. 21(6), pp 1087$1095,2000$.

[6] Norris, D.A., Whang, K., David-Bajar, K., Bennion, S.D., The influence of ultraviolet light on immunological cytotoxicity in the skin. Photochemistry Photobiology. 65(4), pp 636-646, 1997.

[7] Gniadecki, R., Hansen, M., Wulf, H.C., Two pathways for induction of Apoptosis by ultraviolet radiation in cultured human keratinocytes. Journal of Investigative Dermatology 109, pp 163-169, 1997.

[8] Corsini, E., Bruccoleri, A., Marinovich, M., and Galli, M.L., In Vitro mechanism(s) of ultraviolet induced tumor necrosis factor- $\alpha$ release in human keratinocytes cell line. Photodermatology Photoimmunology Photomedicine. 11, pp 112-118, 1995.

[9] Bakand, S., Winder, C., Khalil, C., and Hayes A., A novel in vitro exposure technique for toxicity of selected volatile organic compounds. Journal of Environmental Monioring. 7, pp 1-5, 2005.

[10] Lestari, F., Hayes, A., Green, A.R., and Markovic B., In vitro cytotoxicity of selected chemicals commonly produced during fire combustion using human cell lines Toxicology in Vitro 19, pp 653-663, 2005.

[11] Kalbin, G., Shaoshan, L., Olsman, H., Petterson, M., Engwall, M., Strid, A., Effects of UVB in biological systems: equipments for wavelength dependence determination. Journal of Biochemical and Biophysical Methods 65, pp 1-12, 2005.

[12] Debacq-Chainiaux, F., Borlon, C., Pascal, T., Royer, V., Eliaers, F., Ninane, N., Carrard, G., Friguet, B., de Longueville, F., Boffe, S., Remacle, J., Toussaint, O., Repeated exposure of human skin fibroblasts to UVB at subcytotoxic level triggers premature senescence through the TGF-beta1 signaling pathway. Journal of Cell Science. 118(4), pp 743-58, 2005.

[13] Artiukhova, V.G., Nakvasina, M.A., Lysenko, IuA., Active forms of oxygen and the degree of UV modification of the structural and functional properties of lactate dehydrogenase. Radiatsionnaia Biologiia, Radioecologiia. 37(3), pp 453-460, 1997.

[14] Kimura, H., Minakami, H., Otsuki, K., Shoji, A.: Cu-Zn superoxide dismutase inhibits lactate dehydrogenase release and protects against cell death in murine fibroblasts pretreated with ultraviolet radiation. Cell Biology International. 24(7), pp 459-65, 2000. 